\title{
HAMBATAN-HAMBATAN YANG DIALAMI TUTOR DALAM PEMBELAJARAN PAKET B SETARA SLTP DI SANGGAR KEGIATAN BELAJAR (SKB) LUBUK BEGALUNG KOTA PADANG
}

\begin{abstract}
Nova Devista*
Abstract

Tutors play a very important role in instructional process in B Package Program equivalent to Junior Secondary School as they have to face learners and to plan, organize, and evaluate the instructional process. This research intended to discover obstacles faced by the tutors of $B$ Package Program in Lubuk Begalung in completing their task. This research employed qualitative approach and the data were collected by using observation technique, interview, and document study. The informers were tutors and program executers. The data were analyzed using the method recommended by Miles and Huberman (1992) which was consisted of reducing the data, presenting the data, and drawing the conclusion. The finding of this research shows a set of obstacles faced by the tutors. Beside the efforts have been taken to overcome the obstacles, it is recommended to provide trainings for the tutors and program executors in order to read improve the implementation and the attainment of the obstacles of the program.
\end{abstract}

Key words:

\section{PENDAHULUAN}

\section{Latar Belakang Masalah}

Peningkatan dan pengembangan mutu Sumber Daya Manusia (SDM) tidak terlepas dari peran pendidikan. Pendidikan sebagaimana yang tercantum dalam UU No. 20 tentang Sistem Pendidikan Nasional, bab I pasal 1 adalah usaha sadar dan terencana untuk mewujudkan suasana belajar dan proses pembelajaran agar peserta didik secara aktif mengembangkan potensi didiknya untuk memiliki kekuatan spiritual keagamaan, pengendalian diri, kepribadian, kecerdasan, akhlak mulia serta keterampilan yang diperlukan dirinya, masyarakat, bangsa dan negara.

Untuk itu pemerintah mengusahakan dan menyelenggarakan satu sistem pendidikan nasional yang terdiri atas tiga jalur yaitu jalur pendidikan formal, nonformal dan informal. Pendidikan nonformal (PNF) adalah pendidikan yang diperuntukkan penyelengaraannya bagi warga masyarakat yang memerlukan layanan pendidikan yang berfungsi sebagai pengganti, penambah dan atau pelengkap pendidikan formal dalam rangka mendukung pendidikan sepanjang hayat. PNF pada hakikatnya meliputi

* Pamong Belajar SKB Lubuk Begalung Kota Padang pendidikan kecakapan hidup, pendidikan anak usia dini (PAUD), pendidikan kepemudaan, pendidikan pemberdayaan perempuan, pendidikan keaksaraan, pendidikan keterampilan dan pelatihan kerja, dan pendidikan kesetaraan serta pendidikan lain yang ditujukan untuk mengembangkan kemampuan peserta didik.

Pendidikan kesetaraan sebagai bagian dari PNF adalah program pendidikan yang menyelenggarakan pendidikan umum setara SD/MI, SMP/MTS dan SMA/ MA yang mencakup Program Paket A, Program Paket $B$ dan Paket $C$. Setiap paket merupakan penjenjangan dari masing-masing tingkat pendidikan, Paket Auntuk jenjang pendikan Sekolah Dasar (SD), Program Paket B untuk jenjang pendidikan Sekolah Menengah Pertama (SMP), dan Paket $C$ untuk jenjang pendidikan Sekolah Menengah Atas (SMA). Program ini berupaya melayani peserta didik yang berasal dari masyarakat yang kurang beruntung, tidak pernah sekolah, putus sekolah, tamat pada suatu jenjang pendidikan tertentu tetapi karena berbagai sebab tidak dapat melanjutkan ketingkat yang lebih tinggi (putus lanjut) serta mereka yang berusia produktif yang ingin meningkatkan pengetahuan dan kecakapan hidupnya. Dengan kata lain program kesetaraan merupakan pendidikan pengganti bagi mereka yang tidak berkesempatan mengikuti jenjang pendidikan formal. Hal ini dimaksudkan dan sejalan 
dengan pelaksanaan misi pendidikan nasional yang diantaranya adalah (1) mengupayakan perluasan dan pemerataan kesempatan memperoleh pendidikan yang bermutu bagi seluruh rakyat Indonesia, (2) meningkatkan mutu pendidikan yang memiliki daya saing, (3) meningkatkan relevansi pendidikan dengan kebutuhan masyarakat dan tantangan global, dan (4) meningkatkan keprofesionalan dan akuntabilitas lembaga pendidikan sebagai pusat pembudayaan ilmu pengetahuan, keterampilan, pengalaman, sikap dan nilai berdasarkan standar yang bersifat nasional dan global.

Pasal 26 UU No.20 Tahun 2003 juga menyatakan bahwa hasil Pendidikan Non Formal dihargai setara dengan hasil program pendidikan formal setelah melalui proses penilaian penyetaraan oleh lembaga yang ditunjuk oleh pemerintah atau pemerintah daerah dengan mengacu pada Standar Nasional Pendidikan (SNP). SNP tersebut terdiri dari delapan aspek yang meliputi standar isi, proses, kompetensi lulusan, pendidik dan tenaga kependidikan, sarana prasarana, pengelolaan, pembiayaan, dan standar penilaian. Pernyataan ini secara tidak langsung memberikan implikasi terhadap tanggung jawab dan sekaligus tantangan bagi para penyelenggara PNF bagaimana memberikan layanan pendidikan yang bermutu dan hasil dari program kesetaraan tersebut mempunyai kredibilitas, sehingga betul-betul dapat dihargai setara dengan pendidikan formal.

Menurut Anan Sutisna (Visi, Vol. 2, No.1, 2007:4) penyelenggara pendidikan pada jalur PNF terdiri atas pendidik dan tenaga kependidikan. Pendidik PNF yaitu anggota masyarakat yang memiliki tugas dan kewenangan dalam merencanakan dan melaksanakan proses pembelajaran, menilai hasil pembelajaran, melakukan pembimbingan dan pelatihan. Mereka itu terdiri dari pamong belajar, pendidik PAUD, fasilitator desa intensif, tutor dan tenaga teknis PNF pada dinas pendidikan. Sedangkan Tenaga Kependidikan yaitu anggota masyarakat yang mengabdikan diri dan diangkat untuk menunjang penyelenggaraan $P N F$, yang bertugas melaksanakan administrasi pengelolaan, pengembangan, pengawasan dan pelayanan teknis untuk menunjang proses pendidikan pada satuan PNF. Mereka itu terdiri dari pengelola, penyelenggara PNF, tenaga administrasi, tenaga kepustakaan, narasumber teknis, laboran, penilik dan tenaga lapangan dikmas (Profil PTK-PNF, 2006:6) .

Pada pendidikan kesetaraan, tutor sebagai satu bagian dari komponen tenaga pendidik merupakan ujung tombak dari suatu proses pembelajaran karena mereka berhadapan langsung dengan peserta didik yang bertugas merencanakan, melaksanakan, dan mengevaluasi proses pembelajaran yang dilakukan.
Dengan demikian diharapkan tutor sebagai tenaga pendidik dapat merencanakan, melaksanakan, dan mengevaluasi proses pembelajaran sesuai dengan standar atau kriteria minimal dari berbagai aspek yang terkait dengan proses pembelajaran tersebut (kognitif, afektif dan psikomotor).

Untuk dapat melaksanakan tugas tersebut tentunya tenaga pendidik PNF harus memiliki kompetensi yang dipersyaratkan. Untuk itu Sanggar Kegiatan Belajar (SKB) Lubuk Begalung telah melaksanakan dan mempunyai komitmen untuk selalu melakukan kegiatan-kegiatan peningkatan kompetensi bagi tenaga pendidik seperti melaksanakan seminar, pendidikan dan pelatihan di lingkungan SKB, pembentukan forum tutor dan pengiriman tutor untuk mengikuti diklat yang dilaksanakan di tingkat provinsi. Namun demikian, berdasarkan hasil monitoring dan evaluasi yang dilakukan terhadap kelompok belajar Program Paket B diperoleh gambaran bahwa pada umumnya tutor belum melaksanakan tugas profesinya sebagaimana yang diharapkan seperti: (1) belum memiliki persiapan mengajar yang baik, (2) kegiatan belajar masih dominan menggunakan metode konvensional seperti ceramah dan kurang mengembangkan partisipasi peserta didik untuk berpikir kritis dan analitis terhadap suatu permasalahan, (3) minimnya penggunaan media pembelajaran, dan (4) penilaian proses dan hasil belajar tidak dilaksanakan secara berkelanjutan dan hasil-hasil penilaian tersebut belum diadministrasikan secara baik.

Memperhatikan hal-hal seperti yang diuraikan di atas, maka perlu dilakukan penelitian untuk mengetahui hambatan-hambatan apa saja yang dialami tutor dalam melaksanakan tugas pada pembelajaran Program Paket B setara SLTP di SKB Lubuk Begalung Kota Padang. Terlebih dengan adanya wacana sertifikasi bagi tutor kesetaraan yang dimaksudkan sebagai jaminan terhadap kualitas kinerja tutor dalam merencanakan pengajaran, mendidik dan melaksanakan evaluasi terhadap peserta didik serta menjamin profesionalitas penyelenggara dan pendidik nonformal yang arahnya adalah kualitas dari penyelenggaraan program PNF itu sendiri.

\section{Fokus Penelitian}

Bertolak dari latar belakang masalah di atas, maka yang menjadi fokus penelitian ini adalah berkenaan dengan hambatan-hambatan apa saja yang dialami tutor dalam pembelajaran Program Paket B setara SLTP di SKB Lubuk Begalung Kota Padang.

\section{Pertanyaan Penelitian}

Berdasarkan fokus penelitian yang telah dikemukakan di atas, maka yang menjadi pertaanyaan penelitian adalah: 
1. Hambatan-hambatan apa sajakah yang dialami tutor dalam pembelajaran Program Paket B setara SLTP di SKB Lubuk Begalung?

2. Upaya apa sajakah yang perlu dilakukan untuk mengatasi Hambatan-hambatan yang dialami tutor dalam pembelajaran Program Paket B setara SLTP di SKB Lubuk Begalung?

\section{Tujuan Penelitian}

Penelitian ini bertujuan untuk:

1. Mengungkapkan hambatan-hambatan yang dialami tutor dalam pembelajaran Program Paket B setara SLTP di SKB Lubuk Begalung.

2. Memberikan solusi upaya-upaya yang perlu dilaku- kan untuk mengatasi hambatan-hambatan yang dialami tutor dalam pembelajaran Program Paket B setara SLTP di SKB Lubuk Begalung

\section{Kegunaan Penelitian}

Hasil penelitian ini diharapkan dapat memberi masukan yang bermanfaat kepada:

1. Tutor dalam upaya meningkatkan kinerjanya dalam melaksanakan tugas

2. Penyelenggara program dalam membina tutor melaksanakan tugas

3. Instansi/lembaga lain yang serupa sebagai bahan masukan dalam penyelenggaraan program kesetaraan.

\section{KAJIAN TEORETIS}

\section{Program Paket B Setara SMP}

Program Paket B Setara SMP adalah program pendidikan dasar pada jalur nonformal ditujukan bagi warga masyarakat yang telah lulus SD/MI atau putus SMP/MTS yang tidak sesuai untuk dilayani dengan pendidikan formal/sekolah seperti SMP atau MTS. Ketidaksesuaian tersebut dapat disebabkan oleh faktor umur, keterbatasan sosial, ekonomi, waktu, kesempatan dan lain sebagainya. Sasaran dari Program Paket B setara SMP ini dapat dikelompokkan menurut usia dan status sosial. Menurut usia, sasaran pemberian layanan Program Paket B adalah anak usia wajib belajar dan warga masyarakat di atas usia wajib belajar (orang dewasa). Sedangkan menurut status sosialnya Program Paket B dapat diikuti oleh siapa saja yang telah mendapat pendidikan SD atau setara.

Keputusan Mendikbud No.0131/U/1994 menyatakan pengakuan setara atau berkedudukan sama antara Program Paket B dengan SMP demikian pula dengan UU Pendidikan No. 20 Tahun 2003 pasal 26 ayat 6 yang menyatakan bahwa hasil pendidikan nonformal dapat dihargai setara dengan hasil program pendidikan formal setelah melalui proses penilaian penyetaraan oleh lembaga yang ditunjuk oleh pemerintah atau pemerintah daerah dengan mengacu pada standar nasional pendidikan. Oleh karena itu setiap peserta didik yang lulus ujian kesetaraan Program Paket B mendapatkan ijazah Program Paket $B$ dan mempunyai hak yang sama dan setara dengan pemegang ijazah SMP/MTS untuk dapat melanjutkan pada satuan pendidikan yang lebih tinggi.

Adapun tujuan diselenggarakannya Program Paket B setara SMP ini diantaranya adalah untuk: (1) memfasilitasi pendidikan bagi kelompok masyarakat yang karena sesuatu hal tidak terlayani kebutuhan pendidikannya dengan pola pendidikan lainnya, (2) me- ningkatkan kemampuan peserta didik dalam mengelola sumber daya yang ada di lingkungannya untuk meningkatkan taraf hidupnya. Penekanan dari pelaksanaan Program Paket B tersebut adalah pada aspek penguasaan pengetahuan akademik, keterampilan fungsional, serta pengembangan sikap dan kepribadian profesional peserta didik.

Untuk itu Program Paket B hendaklah dapat: (1) mengembangkan dasar-dasar pembentukan warga negara yang beriman, bertakwa, berkarakter dan bermartabat; (2) meningkatkan kemampuan membaca, menulis, dan berhitung sebagai alat untuk memahami mata pelajaran lainnya; (3) meningkatkan pengalaman belajar yang mandiri, kreatif , dan produktif; (4) memberikan kecakapan hidup untuk bekerja dan berusaha mandiri, serta (5) memberikan bekal pengetahuan, kemampuan, dan sikap dasar yang memungkinkan peserta didik mengikuti pendidikan lanjutan di SMA/ SMK/MA atau Program Paket C. Untuk mencapai maksud di atas dikembangkanlah suatu standar kompetensi dari Program Paket B setara SMP ini yang meliputi: (1) kompetensi kecakapan hidup, (2) kompetensi lulusan, dan (3) kompetensi mata pelajaran.

Menurut Wina Sanjaya (2007) dijelaskan bahwa standar kompetensi kecakapan hidup Program Paket B setara SMP meliputi kecakapan personal, sosial, intelektual, dan vokasional. Selanjutnya Iulusan Program Paket B diharapkan dapat memenuhi standar kompetensi sebagai berikut.

1. Meyakini, memahami, dan menjalankan ajaran agama yang dianutnya dalam bertutur, berbuat, serta berperilaku.

2. Berpikir logis, kritis, kreatif, inovatif, dan memecahkan masalah secara produktif.

3. Berkomunikasi dengan berbagai cara dan media.

4. Memiliki rasa percaya diri untuk berkarya dan mencoba usaha baru yang inovatif dengan 
memanfaatkan lingkungan secara bertanggungjawab.

5. Memahami dan menjalankan hak dan kewajiban dan peduli terhadap sesama.

6. Menerapkan pola hidup bersih, bugar, dan sehat.

7. Menyenangi dan menghargai keindahan serta seni.

8. Bekerjasama dalam tim dan memberi kontribusi.

9. Memiliki bekal untuk melanjutkan ke jenjang pendidikan yang lebih tinggi.

10. Mencintai dan mempercayai negaranya.

Sedangkan standar kompetensi mata pelajaran adalah kemampuan berpikir dan bertindak yang merupakan akumulasi dari pengetahuan, keterampilan, nilai dan sikap yang terkandung dalam masing-masing mata pelajaran dalam Program Paket B setara SMP.

Peran Tutor dalam Pembelajaran Program Paket B

Tutor adalah tenaga pendidik pada Program

Paket B. Menurut juru teknis yang dikeluarkan oleh Dirjen Pendidikan Luar Sekolah dan Pemuda (2004) tutor bertugas merencanakan, melaksanakan proses pembelajaran, dan menilai hasil pembelajaran, serta melakukan pembimbingan dan pelatihan. Sejalan dengan itu PP No. 19 Tahun 2005 tentang Standar Nasional Pendidikan, mensyaratkan bahwa pendidik harus memiliki kualifikasi akademik dan kompetensi sebagai agen pembelajaran.

Kualifikasi akademik adalah tingkat pendidikan minimal yang harus dipenuhi oleh seorang pendidik yang dibuktikan dengan ijazah dan atau sertifikat keahlian yang relevan, yang dalam hal ini tutor Program Paket $B$ harus memiliki kualifikasi akademik pendidikan minimum Diploma Empat (D-IV) atau Sarjana (S-1) dan memiliki latar belakang pendidikan tinggi dengan program pendidikan yang sesuai dengan mata pelajaran yang diajarkan. Sedangkan kompetensi sebagai agen pembelajaran (learning agent) meliputi kompetensi pedagogik, kompetensi kepribadian, kompetensi profesional dan kompetensi sosial.

Kegiatan pembelajaran pada Program Paket B adalah pembelajaran untuk berbagai bidang mata pelajaran yang konversinya sama dengan di SMP, dengan demikian peran guru di SMP identik dengan peran tutor di Program Paket B. Mereka harus melaksanakan proses belajar mengajar yang terencana, terorganisir, dan terprogram.

Dalam melaksanakan tugasnya seorang tutor berkewajiban menyusun rencana pembelajaran yang akan diajarkan pada peserta didik. Pada tahap ini tutor akan berusaha mendeskripsikan tujuan pembelajaran, menentukan materi dan kompetensi yang diharapkan, mengorganisasikan urutan penyampaian materi, mengalokasikan waktu, menentukan metode dan prosedur pembelajaran, menentukan media dan sumber belajar yang sesuai serta menentukan teknik penilaiannya. Dengan adanya rencana pembelajaran maka proses pembelajaran menjadi terarah, memiliki pedoman, kendali, dan panduan yang jelas.

Tugas tutor dalam melaksanakan pembelajaran meliputi antara lain menyajikan pelajaran dengan metode yang sesuai dengan materi pelajaran, menggunakan media pembelajaran, dan menggunakan sumber belajar sehingga menciptakan interaksi dengan peserta didik, selain itu juga memberikan umpan balik dan menyimpulkan materi pelajaran sehingga proses belajar mengajar berlangsung secara efektif dan efisien.

Berkaitan dengan tugas tutor dalam menilai prestasi belajar peserta didik, seorang tutor diharapkan mampu membuat instrumen penilaian berdasarkan indikator kompetensi yang hendak dicapai, mengolah hasil belajar, dan memberikan penilaian akhir prestasi belajar siswa.

\section{METODOLOGI PENELITIAN}

\section{Pendekatan Penelitian}

Sebagaimana paparan di atas, permasalahan yang akan diteliti dalam penelitian ini adalah hambatanhambatan yang dialami tutor dalam pembelajaran Program Paket B setara SMP di SKB Lubuk Begalung Kota Padang. Pengkajian tentang hambatan-hambatan yang dialami tutor dalam melaksanakan tugasnya pada dasarnya adalah berhubungan dengan eksplorasi terhadap sikap, pandangan, dan perilaku tutor dalam melaksanakan tugas profesionalnya sebagai tenaga edukatif. Sehubungan dengan itu, peneliti memilih metode kualitatif sebagai metode yang tepat untuk digunakan. Menurut Moleong (2004:5) penelitian kualitatif merupakan penelitian yang memanfaatkan wawancara terbuka untuk menelaah dan memahami sikap, pandangan, perasaan, dan perilaku individu atau sekelompok orang.

Berkaitan dengan itu Jane Richie dalam Moleong (2004:6) menyatakan bahwasanya penelitian kualitatif adalah upaya untuk menyajikan dunia sosial dan perspektifnya di dalam dunia dari segi konsep, perilaku, dan persepsi tentang manusia yang diteliti. Lebih jauh Moleong menjelaskan bahwa penelitian kualitatif adalah penelitian yang bermaksud untuk memahami fenomena tentang apa yang dialami oleh subjek penelitian misalnya perilaku, persepsi, motivasi, tindakan dan lain- 
lain secara holistik, dengan cara deskripsi dalam bentuk kata-kata dan bahasa pada suatu konteks khusus yang alamiah serta dengan memanfaatkan berbagai metode alamiah.

Melalui penelitian ini diharapkan peneliti dapat menemukan latar belakang atau proses dari fenomena yang mempengaruhi pelaksanaan tugas tutor Program Paket B di SKB Lubuk Begalung dari aspek hambatan atau kesulitan yang dialami secara mendalam yang tidak dapat diteliti melalui penelitian kuantitatif.

\section{Langkah-langkah Penelitian}

Banyak pendapat dari para ahli sehubungan dengan tahap-tahap yang perlu dijalankan dalam mempelajari sesuatu melalui penelitian kualitatif. Gambaran tentang keseluruhan perencanaan, pelaksanaan pengumpulan data, analisis, dan penafsiran data serta penulisan laporan akan dijelaskan dalam tahapan berikut.

Spradley dalam bukunya Participant Observation (1980:37) menyatakan beberapa langkah dalam penelitian kualitatif, yaitu: (1)localizing a social situation, (2) using participant observation, (3) making an ethnographic record, (4) making describe observation, (5) making a domain analysis, (6) making focused observation, (7) making a taxonomic analysis, (8) making selected observation, (9) making a componential analysis, (10) discovering cultural themes, (11) taking a cultural inventory, (12) writing an ethnography.

Menurut Faisal (1990:21) proses penelitian kualitatif biasanya menggunakan proses yang berbentuk siklus. Siklus penelitian dimulai dengan memilih proyek penelitian, kemudian diteruskan dengan mengajukan pertanyaan-pertanyaan yang berkaitan dengan proyek penelitian, mengumpulkan data yang menyangkut pertanyaan-pertanyaan dimaksud tadi, menyusun catatan data yang telah dikumpulkan dan menganalisisnya.

Danim (2002:51) mengemukakan bahwa aplikasi metode kualitatif dalam penelitian ilmu-ilmu sosial dilakukan dengan langkah-langkah yaitu: merumuskan masalah sebagai fokus penelitian, mengumpulkan data lapangan, menganalisis data, merumuskan hasil studi, dan menyusun rekomendasi.

Bogdan dalam Moleong (2004:126) menyajikan tiga tahapan penelitian kualitatif yaitu: (1) pra lapangan, (2) kegiatan lapangan, (3) analisis intensif. Kemudian Moleong menambahkan satu langkah lagi yaitu tahap penulisan laporan.

Penelitian ini dilakukan dengan menggunakan langkah-langkah sebagaimana yang dikemukakan Bogdan dan Moleong adalah sebagai berikut.

\section{Pra Lapangan}

Pada tahap ini ada beberapa kegiatan yang harus dilakukan peneliti seperti menyusun rancangan penelitian, memilih lapangan penelitian, menjajaki dan menilai lapangan, memilih dan memanfaatkan informan serta menyiapkan perlengkapan penelitian. Dalam hal ini yang perlu dijelaskan adalah bagaimana memilih lapangan penelitian atau yang pada banyak penelitian kualitatif disebut juga sebagai tahap menentukan situasi sosial.

Adapun situasi sosial yang dipilih untuk dikaji dalam penelitian ini adalah kelompok belajar (tutor) Program Paket B setara SMP pada Sanggar Kegiatan Belajar (SKB) Lubuk Begalung Kota Padang. Dalam hal ini pemilihan kelompok belajar Program Paket B pada SKB Lubuk Begalung sebagai objek penelitian tidak dimaksudkan untuk mewakili kelompok belajar Program Paket B yang ada pada daerah lain, tetapi khusus mengkaji tentang fenomena pelaksanaan tugas tutor Program Paket B yang ada pada SKB Lubuk Begalung. Hal ini sejalan dengan pendapat Moleong (2004:31) bahwa dalam penelitian kualitatif upaya generalisasi tidak dikenal karena perilaku manusia selalu terikat konteks dan harus diinterpretasikan kasus per kasus.

2. Melakukan Kegiatan Lapangan

Kegiatan lapangan yang dilakukan adalah berupa observasi atau pengamatan. Pengamatan termasuk teknik pengumpulan data yang utama dalam kebanyakan penelitian kualitatif. Mengumpulkan data merupakan langkah yang tidak dapat dihindari dalam kegiatan penelitian dengan pendekatan apapun, termasuk pada penelitian kualitatif. Pengumpulan data merupakan fase yang sangat strategis untuk menghasilkan penelitian yang bermutu.

Karena penelitian kualitatif kebanyakan berhubungan dengan fenomena dan peneliti adalah sebagai instrumen utama maka kehadiran peneliti mutlak diperlukan untuk mengetahui secara langsung kondisi dan fenomena di lapangan.

Observasi lapangan yang diakukan untuk penelitian ini adalah berupa grand tour dan mini tour. Grand tour merupakan pengamatan yang dilakukan secara umum dan sebagai kelanjutannya dilakukan mini tour, yaitu pengamatan yang telah terfokus guna memperoleh data yang lebih terperinci.

Selama melakukan penelitian, peneliti melakukan observasi langsung ke tempat penelitian dan membuat catatan lapangan tentang apa yang dilihat, didengar, dialami, dan dipikirkan peneliti dalam rangka pengumpulan data serta pemberian makna terhadap fenomena yang ada.

3. Melakukan Analisis Data 
Kegiatan yang dilakukan dalam proses analisis data adalah menyangkut pelacakan, pengorganisasian, sintesis data, dan pencarian pola serta penentuan halhal yang akan dilaporkan sesuai dengan fokus penelitian.

Analisis data dalam penelitian ini dilakukan secara berkelanjutan, terus menerus, dan berulang selama proses pengumpulan data dan setelah pengumpulan data berakhir. Analisis data selama proses pengumpulan data dimaksudkan untuk mengumpulkan data yang ada serta memikirkan data baru yang akan dikumpulkan, mencari kebenaran informasi yang masih kabur, dan mengecek serta mengarahkan analisis yang sedang berjalan. Sedangkan analisis data setelah pengumpulan data pada prinsipnya adalah kelanjutan dari analisis sebelumnya, dalam hal ini peneliti melengkapi dan memaparkan data secara sistematis serta memastikan konsep atau pola yang telah dibangun berdasarkan data lapangan.

Proses pengumpulan data dihentikan apabila tidak ditemukan lagi variasi informasi baru atau telah terjadi pengulangan informasi yang sama berkaitan dengan fokus penelitian. Selain itu adalah apabila informasi yang dibutuhkan telah terangkum secara menyeluruh dan rinci.

4. Membuat Laporan Hasil Penelitian

Setelah melaksanakan analisis data secara kualitatif, tugas peneliti selanjutnya adalah menulis laporan penelitian. Secara umum, tujuan penulisan laporan adalah untuk melaporkan proses dan hasil kerja penelitian agar dapat dikonsumsi oleh pemakai atau pihak-pihak yang berkepentingan.

\section{Teknik Pengumpulan Data}

Data yang diperlukan dalam penelitian ini diperoleh dengan menggunakan teknik observasi, wawancara dengan informan, dan pengkajian dokumen.

1. Observasi

Observasi atau pengamatan dalam penelitian kualitatif adalah salah satu teknik pengumpulan data yang utama untuk mengkaji situasi sosial di lapangan. Kajian yang menjadi observasi peneliti adalah peristiwa, kegiatan-kegiatan, dan perilaku tutor yang berkaitan dengan tugas, tanggung jawab, dan peranannya dalam kelompok belajar.

\section{Wawancara}

Menyadari bahwa tidak semua data dapat diperoleh melalui observasi, maka selain observasi digunakan pula wawancara. Wawancara adalah proses percakapan yang bertujuan untuk mengkonstruksi halhal mengenai orang, kejadian, organisasi, motivasi, dan perasaan yang dilakukan oleh kedua pihak yaitu pewawancara (interviewer) dan yang diwawancarai (interviewee).

Sebagaimana dikemukakan Lincoln dan Guba, seperti yang dikutip Faisal (1990) menjelaskan bahwa kegiatan wawancara meliputi sejumlah langkah-langkah yaitu antara lain: (1) menetapkan kepada siapa wawancara dilakukan, (2) menetapkan pokok masalah yang menjadi bahan pembicaraan, (3) mengawali atau membuka alur wawancara, (4) melangsungkan wawancara, (5) menulis hasil wawancara, dan (6) mengidentifikasi hasil wawancara.

3. Studi Dokumentasi

Di samping menggunakan observasi dan wawancara, data penelitian juga diperoleh dari dokumen atau catatan yang berupa pengumuman, surat tugas atau surat keputusan, instruksi, aturan-aturan, laporan, catatan-catatan (absensi), dan arsip lain yang berhubungan dengan fokus penelitian.

\section{Informan Penelitian}

Dalam rangka mendapatkan informasi sebanyak mungkin dibutuhkan orang-orang yang mengetahui, memahami, dan dapat meluangkan waktu serta dapat dipercaya untuk memberikan data-data yang dibutuhkan. Orang-orang tersebut dinamakan informan.

Dalam pemilihan informan ini, oleh Spradley disarankan untuk memenuhi persyaratan berikut.

1. Mereka yang bukan sekedar mengetahui tetapi menguasai atau memahami situasi dan kondisi yang ada.

2. Mereka yang masih berkecimpung atau terlibat pada kegiatan yang sedang diteliti.

3. Mereka yang mempunyai kesempatan/waktu yang memadai untuk dimintai informasi.

4. Mereka yang tidak cenderung menyampaikan informasi hasil kemasan sendiri.

5. Mereka yang pada mulanya tergolong cukup asing dengan peneliti tetapi dapat dijadikan narasumber.

Dalam penelitian ini yang menjadi informan adalah tutor dan pengelola Program Paket B setara SLTP pada SKB Lubuk Begalung yang dianggap mengetahui dan dapat memberikan informasi yang dibutuhkan. Kegiatan penggalian informasi atau pembaruan data akan bergulir menggelinding sedemikian rupa laksana bola salju (snow ball) sehingga variasi, kedalaman, dan keterincian data/informasi dapat diperoleh secara maksimal. Bila data yang ditemukan tidak lagi memunculkan variasi informasi yang signifikan dengan fokus penelitian maka pencarian informasi baru akan dihentikan.

\section{Teknik Analisis Data}

Analisis data kualitatif menurut Bogdan dan Biklen (1982) adalah upaya yang dilakukan dengan jalan 
bekerja dengan data, mengorganisasikan data, memilah-milahnya menjadi satuan yang dapat dikelola, mensintesiskannya, mencari dan menemukan pola, menemukan apa yang dianggap penting dan apa yang dipelajari, serta memutuskan apa yang dapat diceritakan kepada orang lain.

Miles dan Huberman dalam Rohidi (1992:16) menyatakan bahwa analisis data terdiri atas tiga alur kegiatan yang terjadi secara bersamaan yaitu reduksi data, penyajian data, dan penarikan kesimpulan/ verifikasi. Penelitian ini menggunakan pendekatan analisis data sebagaimana yang dianjurkan Miles dan Huberman.

Kegiatan dalam analisis data ini merupakan suatu siklus yang interaktif sebelum, selama, dan sesudah pengumpulan data berakhir. Secara skematis analisis data dapat digambarkan sebagai berikut:

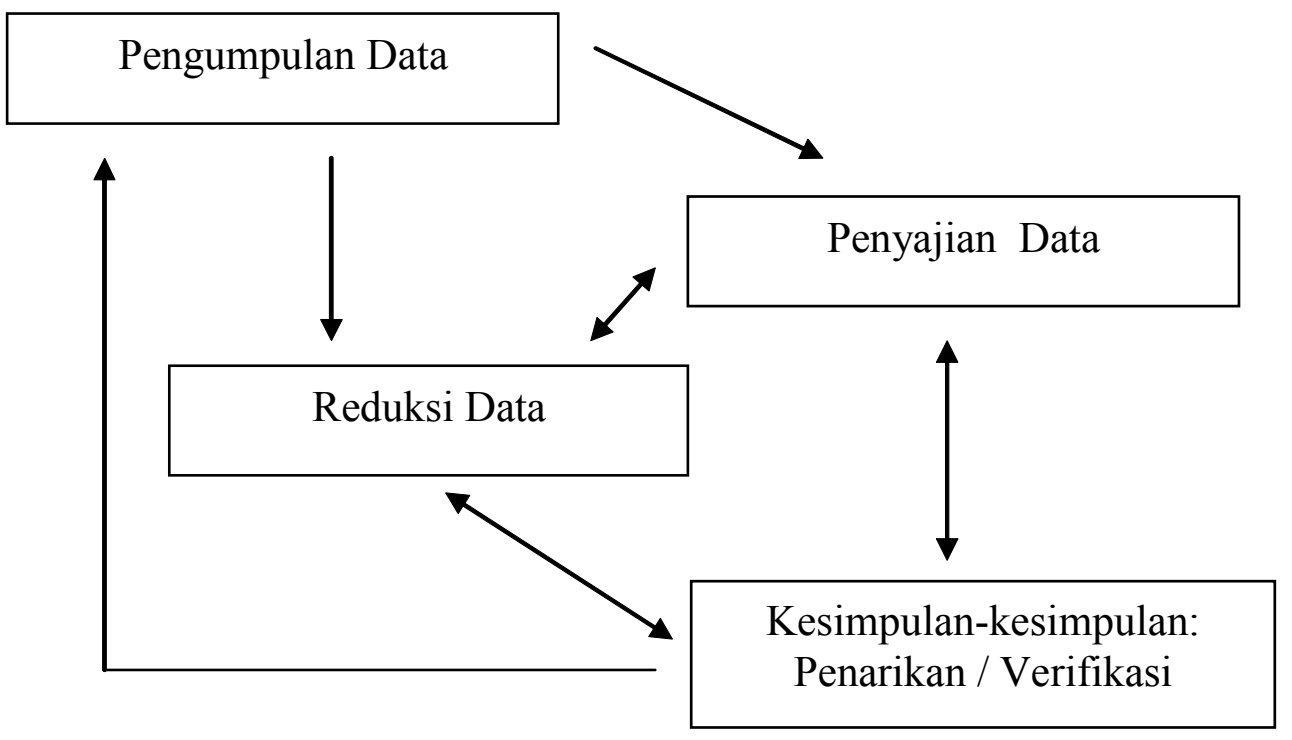

Gambar 1. Model Analisis Data

\section{Instrumen Penelitian}

Sebagaimana lazimnya dalam penelitian kualitatif maka pada penelitian ini, peneliti adalah instrumen kunci. Namun demikian, di samping peneliti sebagai instrumen, pengumpulan data juga menggunakan bantuan instrumen lain sebagai penunjang seperti catatan dan dokumen lain yang berkaitan dengan fokus penelitian.

\section{Pengecekan Keabsahan Data}

Untuk memperoleh keabsahan temuan, perlu digunakan suatu kriteria tertentu. Lincoln dan Guba dalam Faisal (1990:31) menyarankan empat kriteria utama yaitu sebagai berikut. (1) Keterpercayaan (credibility). (2) Keteralihan (transferability). (3) Keterandalan (dependability). (4) Kepastian (confirmability).

\section{HASIL PENELITIAN}

\section{Temuan Umum}

1. Landasan Yuridis

Adapun landasan yuridis yang terkait langsung dengan penyelenggaraan Program Paket B setara SMP antara lain sebagai berikut.

a. UU No. 20 Tahun 2003 tentang Sistem Pendidikan Nasional.

b. PP RI No. 73 Tahun 1991 tentang Pendidikan Luar Sekolah.

c. PP RI No. 19 Tahun 2005 tentang Standar Nasional Pendidikan.

d. Instruksi Presiden No. 01 Tahun 1994 tentang Wajib Belajar 9 Tahun. e. Kepmendikbud No. 0131/U/1994 tentang Pengakuan Setara dan Berkedudukan Sama Program Paket B dengan SMP.

f. Kepmendiknas No. 86/U/2003 tentang Ujian Persamaan dan Pengalihan Layanan Ujian Persamaan SMP oleh Paket B.

g. SK Walikota Padang No. 54 Tahun 2001 tentang Rincian Tugas Pokok SKB.

Berdasarkan landasan yuridis tersebut, SKB Lubuk Begalung menyelengarakan kelompok belajar Program Paket B dan untuk tahun 2007/2008 penyelenggaraan terdapat tidak saja berlokasi di SKB Lubuk Begalung, tetapi juga berada di luar SKB Lubuk Begalung. Penelitian ini hanya difokuskan pada 
Hambatan-hambatan yang Dialami Tutor...

kelompok belajar yang berlokasi pada SKB Lubuk Begalung.

\section{Warga Belajar}

Warga Belajar (WB) adalah sebutan bagi peserta didik pada program pendidikan kesetaraan ataupun program pendidikan luar sekolah lainnya. WB yang merupakan sasaran dari Program Paket B ini adalah anak yang telah tamat SD/MI/Paket A dan anak yang putus sekolah.

Adapun keadaan WB Program Paket B setara SMP tahun pelajaran 2007/2008 di SKB Lubuk Begalung menurut jenis kelamin dan usia dapat dilihat melalui tabel-tabel berikut.

Tabel 1. Keadaan Warga Belajar Program Paket B Setara SMP Tahun Pelajaran 2007/2008

Lokasi Belajar Pada SKB Lubuk Begalung Kota Padang Menurut Jenis Kelamin.

\begin{tabular}{|c|c|c|c|c|c|}
\hline \multirow[t]{2}{*}{ No } & \multirow[t]{2}{*}{ Kelas } & \multicolumn{3}{|c|}{ Jumlah Warga Belajar } & \multirow[t]{2}{*}{ Keterangan } \\
\hline & & L & $P$ & Jumlah & \\
\hline 1 & 1 & 5 & 4 & 9 & \\
\hline 2 & 2 & 5 & 8 & 13 & \\
\hline \multirow[t]{2}{*}{3} & 3 & 10 & 7 & 17 & \\
\hline & Total & 20 & 19 & 39 & \\
\hline
\end{tabular}

Tabel 2. Keadaan Warga Belajar Program Paket B Setara SMP Tahun Pelajaran 2007/2008

Lokasi Belajar pada SKB Lubuk Begalung Kota Padang Menurut Usia

\begin{tabular}{|l|c|c|c|c|c|}
\hline \multirow{2}{*}{ No } & \multirow{2}{*}{ Kelas } & \multicolumn{3}{|c|}{ Usia (tahun) } & \multirow{2}{*}{ Jumlah } \\
\cline { 3 - 5 } & & $12-13$ & $14-15$ & $16-17$ & \\
\hline 1 & 1 & 2 & 5 & 2 & 9 \\
\hline 2 & 2 & 1 & 9 & 3 & 13 \\
\hline 3 & 3 & - & 13 & 4 & 17 \\
\hline & Jumlah & 3 & 27 & 9 & 39 \\
\hline
\end{tabular}

\section{Tenaga Pendidik}

Tenaga pendidik pada pendidikan kesetaraan disebut dengan tutor. Warga masyarakat dapat menjadi tutor Program Paket B apabila memenuhi kriteria (Dirjen PLSP, 2005:11) berikut ini.

a. Memiliki kompetensi personal dan sosial, berakhlak mulia, sabar, berdedikasi, ikhlas, disiplin, memiliki etos kerja yang tinggi, serta memiliki jiwa kebersamaan dan sosial.

b. Berpendidikan sekurang-kurangnya D3 atau S1 dengan bidang studi yang sama dengan mata pelajaran yang diusulkan. c. Menguasai materi pelajaran yang diusulkan.

d. Mampu mengelola dan mengembangkan proses pembelajaran yang sesuai dengan karakteristik dan kebutuhan peserta didik berdasarkan kurikulum yang berlaku.

e. Menguasai dan mampu mengembangkan teknik/ metode pembelajaran.

f. Memiliki komitmen tinggi terhadap tugas dan kewajibannya sebagai tutor yang dilandasi dengan semangat pengabdian.

Adapun data tutor Program Paket B di SKB Lubuk Begalung terdapat pada tabel sebagai berikut. 
Tabel 3. Data Tutor Program Paket B di SKB Lubuk Begalung

\begin{tabular}{|c|c|c|c|c|c|}
\hline Nama & L/P & $\begin{array}{l}\text { Usia } \\
\text { (tahun) }\end{array}$ & $\begin{array}{c}\text { Pendidikan/ Bidang } \\
\text { ilmu }\end{array}$ & $\begin{array}{c}\text { Mata } \\
\text { Pelajaran } \\
\text { yang } \\
\text { diajarkan }\end{array}$ & $\begin{array}{c}\text { Frekuensi mengikut } \\
\text { Diklat/ seminar } \\
\text { Kesetaraan }\end{array}$ \\
\hline Fitri, S.Pd & $\mathrm{P}$ & 23 & S1/PLS & $\begin{array}{l}\text { BAM } \\
\text { Biologi }\end{array}$ & 4 \\
\hline Sarmelia, S.Pd & $\mathrm{P}$ & 27 & S1/B.Inggris & B.Inggris & 3 \\
\hline Ida Corina, S.Pd & $P$ & 36 & S1/B.Indonesia & B.Indonesia & 3 \\
\hline Yulihartina, SE & $P$ & 38 & S1/Matematika & Matematika & 3 \\
\hline Zulkifli & $L$ & 47 & D1/PLS & Pramuka & $>4$ \\
\hline Nofiardi & L & 26 & $\begin{array}{c}\text { SLTA } \\
\text { (Mhs prog S1 } \\
\text { Matematika) }\end{array}$ & $\begin{array}{l}\text { Ekonomi } \\
\text { Matematika } \\
\text { Fisika }\end{array}$ & 3 \\
\hline Rosita S & $P$ & 48 & D1/ PLS & Kesenian & $>4$ \\
\hline Rahmawati & $\mathrm{P}$ & 32 & $\begin{array}{c}\text { SLTA } \\
\text { (Mhs prog S1 } \\
\text { Biologi) }\end{array}$ & $\begin{array}{l}\text { Fisika } \\
\text { Boilogi }\end{array}$ & 4 \\
\hline Ekthofia, S.Ag & $\mathrm{P}$ & 37 & S1/IAIN & $\begin{array}{l}\text { Agama } \\
\text { BAM }\end{array}$ & 4 \\
\hline Wilda M, S.Pd & $P$ & 30 & S1/ Geografi & Geografi & 3 \\
\hline Nofriadi, SE & $L$ & 29 & S1/Ekonomi & Ekonomi & 4 \\
\hline Arizona, S.Pd & $P$ & 22 & S1/PLS & Sejarah & 3 \\
\hline Dewi Septiati & $\mathrm{P}$ & 23 & $\begin{array}{c}\text { SLTA } \\
\text { (Mhs prog S1 PLS) }\end{array}$ & PPKN & 3 \\
\hline M.Tajib & L & & $\begin{array}{c}\text { SLTA } \\
\text { (Mhs prog S1 PLS) }\end{array}$ & Olah Raga & 3 \\
\hline
\end{tabular}

\section{Penyelenggara/Pengelola Program}

Masing-masing kelas/kelompok belajar Program

Paket B di SKB Lubuk Begalung dikelola oleh tiga orang pamong belajar. Data penyelenggara atau pengelola Program Paket B di SKB Lubuk Begalung Kota Padang tersebut seperti terdapat pada tabel berikut ini.

Tabel 4. Data Penyelenggara/Pengelola Program Paket B di SKB Lubuk Begalung

\begin{tabular}{|r|l|c|c|c|c|c|}
\hline No & Nama & LP & $\begin{array}{c}\text { Usia } \\
\text { (tahun) }\end{array}$ & Pendidikan & $\begin{array}{c}\text { Masa Kerja } \\
\text { (tahun) }\end{array}$ & Golongan \\
\hline \hline 1 & Sastra,M.Pd & L & 46 & S2 & 19 & IIId \\
\hline 2 & Yulizarni & P & 52 & SLTA & 30 & Illa \\
\hline 3 & Nurfauz & P & 49 & SLTA & 30 & IIIc \\
\hline 4 & Dra.Emawati & P & 39 & S1 & 14 & IIIc \\
\hline 5 & Zulkifli & L & 47 & D1 & 27 & IIId \\
\hline 6 & Rosmaini & P & 51 & SLTA & 32 & Illb \\
\hline 7 & Rosita S & P & 48 & D1 & 27 & IIIc \\
\hline 8 & Dra.Eva Defriani & P & 46 & S1 & 20 & IIId \\
\hline
\end{tabular}


Hambatan-hambatan yang Dialami Tutor...

\section{Program Pembelajaran}

Berdasarkan kesepakatan antara warga belajar dan penyelenggara, pembelajaran Program Paket $B$ di SKB Lubuk Begalung diselenggarakan setiap hari dari pukul 08.00-12.30. Alokasi waktu untuk 1 (satu) jam pelajaran adalah 40 menit. Adapun jadwal pelajaran untuk kelas 1, 2, dan 3 dapat diketahui melalui tabel sebagai berikut.

Tabel 5. Jadwal Pelajaran Kelas 1, 2, dan 3 Program Paket B di SKB Lubuk Begalung

\begin{tabular}{|c|c|c|c|c|}
\hline Hari & Jam & Kelas I & Kelas II & Kelas III \\
\hline \multirow[t]{7}{*}{ Senin } & $08.00-08.40$ & Matematika & Fisika & Matematika \\
\hline & $08.40-09.20$ & sda & sda & sda \\
\hline & $09.20-10.00$ & sda & sda & sda \\
\hline & $10.00-10.30$ & - & - & - \\
\hline & $10.30-11.10$ & B. Indonesia & Matematika & Fisika \\
\hline & $11.10-11.50$ & sda & sda & sda \\
\hline & $11.50-12.30$ & sda & sda & sda \\
\hline \multirow[t]{7}{*}{ Selasa } & $08.00-08.40$ & Fisika & Biologi & Sejarah \\
\hline & $08.40-09.20$ & sda & sda & sda \\
\hline & $09.20-10.00$ & sda & Agama & Biologi \\
\hline & $10.00-10.30$ & - & - & - \\
\hline & $10.30-11.10$ & B.Inggris & Agama & Biologi \\
\hline & $11.10-11.50$ & sda & Sejarah & Agama \\
\hline & $11.50-12.30$ & sda & sda & sda \\
\hline \multirow[t]{7}{*}{ Rabu } & $08.00-08.40$ & Agama & B.Inggris & B.Indonesia \\
\hline & $08.40-09.20$ & sda & sda & sda \\
\hline & $09.20-10.00$ & Sejarah & sda & sda \\
\hline & $10.00-10.30$ & - & - & - \\
\hline & $10.30-11.10$ & Sejarah & B.Indonesia & B.Inggris \\
\hline & $11.10-11.50$ & Ekonomi & sda & sda \\
\hline & $11.50-12.30$ & sda & sda & sda \\
\hline \multirow[t]{7}{*}{ Kamis } & $08.00-08.40$ & Kesenian & PPKN & Ekonomi \\
\hline & $08.40-09.20$ & sda & sda & sda \\
\hline & $09.20-10.00$ & PPKN & Ekonomi & Kesenian \\
\hline & $10.00-10.30$ & - & - & - \\
\hline & $10.30-11.10$ & PPKN & Ekonomi & Kesenian \\
\hline & $11.10-11.50$ & Geografi & Kesenian & PPKN \\
\hline & $11.50-12.30$ & sda & sda & sda \\
\hline \multirow[t]{4}{*}{ Jum'at } & $08.00-08.40$ & BAM & Geografi & BAM \\
\hline & $08.40-09.20$ & sda & sda & sda \\
\hline & $09.20-10.00$ & Biologi & BAM & Geografi \\
\hline & $10.00-10.30$ & - & - & - \\
\hline
\end{tabular}




\section{Temuan Khusus}

1. Hambatan-Hambatan yang Dialami Tutor dalam Pembelajaran Program Paket B Di SKB Lubuk Begalung

Sebagaimana paparan di atas, tutor bertugas merencanakan, melaksanakan, dan mengevaluasi pembelajaran. Sejalan dengan itu, Dirjen PLSP (2005:11) menyatakan bahwa tutor berkewajiban antara lain: (1) membimbing dan membantu pembelajaran peserta didik dalam kelompok belajar, (2) menyusun rencana pembelajaran yang akan diajarkan pada peserta didik, (3) membuat bahan belajar/media belajar sesuai dengan kebutuhan materi pelajaran, dan (4) menilai kemajuan belajar peserta didik.

Penulisan laporan penelitian ini difokuskan pada hambatan-hambatan yang dialami tutor dalam merencanakan, melaksanakan, dan mengevaluasi pembelajaran Program Paket B setara SMP di SKB Lubuk Begalung kota Padang.

a. Hambatan dalam menyusun perencanaan pembelajaran

Berdasarkan observasi dan wawancara yang dilakukan, kemudian diolah dengan trianggulasi data diketahui bahwa hambatan-hambatan atau kesulitan yang dialami tutor dalam merencanakan pembelajaran pada kelompok belajar Program Paket B setara SMP di SKB Lubuk begalung di antaranya: (1) kurangnya ketersediaan kurikulum, dan (2) kurangnya petunjuk teknis pelaksanaan oleh pengelola program.

Hal ini dialami hampir oleh semua tutor yang mengajar pada kelas 1, 2, maupun 3; dimana tidak semua mata pelajaran yang diajarkan mempunyai kurikulum kesetaraan disamping itu tutor juga tidak memiliki standar suatu petunjuk teknis pelaksanaan pembelajaran yang jelas. Padahal kurikulum pada prinsipnya sangat diperlukan terutama dalam merencanakan kegiatan pembelajaran yang akan dilaksanakan karena kurikulum merupakan pedoman atau panduan bagi tutor dalam membuat perencanaan pengajaran. Berkenaan dengan ini, beberapa orang tutor menyampaikan informasi di antaranya seperti wawancara tanggal 25 Oktober 2007, seorang tutor menyatakan:

"sebagian mata pelajaran ada kurikulumnya, sebagian ada yang tidak, jadi kami kesulitan membuat SP. Sampai saat ini kami menggunakan kurikulum dan bahan-bahan dari sekolah formal dan juga mempedomani soal-soal ujian Program Paket $B$ yang dari dinas dan ujian nasional"

Tutor yang lain mengemukakan:

"mata pelajaran yang saya ajarkan ini tidak ada kurikulum Program Paket B nya, juga tidak ada ketentuan kalau pakai kurikulum SMP yang KBKnya atau KTSP. Hendaknya kan ada ketetapan tentang apa yang harus diajarkan dan ada kurikulumnya. Jadi ada pegangan dan enak kalau mau buat SP. Ditambah lagi tidak ada pula arahan yang jelas bagaimana seharusnya teknis pembelajaran pada Program Paket B ini”.

Mendapat informasi tersebut peneliti menanyakan kepada salah seorang pengelola program tentang kurikulum yang digunakan. Informasi yang disampaikan adalah sebagai berikut:

"Pedoman pengajaran sebagian menggunakan kurikulum Program Paket B tahun 2004, modul, dan menyesuaikan dengan yang digunakan di sekolah. Memang tidak semua mata pelajaran kurikulumnya kita miliki. Semua itu diserahkan atau dipercayakan pada tutor yang bersangkutan apa yang akan diajarkan, termasuk juga bagaimana teknis pelaksanaan pembelajarannya."

b. Hambatan dalam melaksanakan pembelajaran

Adapun hambatan-hambatan yang ditemui tutor dalam melaksanakan proses pembelajaran pada Program Paket B setara SLTP di SKB Lubuk Begalung berdasarkan temuan peneliti adalah sebagai berikut.

1. Kurangnya ketersediaan sarana dan prasarana pendukung proses belajar mengajar.

2. Kurangnya ketersediaan rujukan dan buku sumber bagi wajib belajar.

3. Kurangnya pengawasan dan pengendalian oleh pengelola program terhadap tutor (kurangnya komunikasi antara pengelola dan tutor).

Berdasarkan pengamatan yang dilakukan peneliti, diketahui bahwa sarana dan prasarana pembelajaran untuk Program Paket B setara SLTP pada SKB Lubuk Begalung baru terbatas pada ruangan kelas, meja dan kursi belajar, serta papan tulis, namun belum didukung oleh alat bantu atau media pembelajaran seperti flip chart, ohp atau proyektor. Di samping itu, rujukan dan buku masih terbatas pada modul dan buku ajar yang dimiliki atau dipegang oleh tutor namun belum oleh semua siswa.

Pada bagian lain, komunikasi antara pengelola program dan tutor terlihat masih kurang, hal ini antara lain terungkap dari pernyataan tutor sebagai berikut.

"Selama ini kami jarang berkomunikasi dengan pengelola untuk mendiskusikan bagaimana sebaiknya proses belajar mengajar dilakukan. Sepertinya pengelola menyerahkan sepenuhnya kepada tutor. Pengelola hanya menunjuk piket secara bergantian untuk memantau kehadiran tutor dan memeriksa kebersihan kelas."

c. Hambatan dalam menilai kemajuan belajar 
Dalam melakukan evaluasi pembelajaran Program Paket B setara SMP di SKB Lubuk Begalung kota Padang, peneliti menemukan hambatan-hambatan yang dialami oleh tutor adalah sebagai berikut.

1. Belum dilakukannya perencanaan pembelajaran dengan baik mengakibatkan kesulitan untuk melakukan evaluasi karena tidak ada patokan yang jelas baik proses maupun hasil belajar atau kompetensi yang seharusnya ditampilkan.

2. Kurangnya pengarahan dan pembinaan oleh pengelola program terhadap tutor, khususnya mengenai tolok ukur penilaian kemajuan belajar warga belajar.

Hal tersebut di atas antara lain tercermin dari pernyataan seorang tutor sebagai berikut.

"Evaluasi yang digunakan kadang-kadang lisan, atau ada juga diadakan evaluasi secara tertulis dalam dua minggu sekali. Sejauh ini pengelola pun menyerahkan sepenuhnya masalah evaluasi ini kepada tutor."

Berdasarkan uraian di atas, maka proses evaluasi tidak dapat berdiri sendiri tetapi merupakan satu kesatuan dengan perencanaan maupun proses pembelajaran.

2. Upaya yang Dilakukan oleh SKB Lubuk Begalung dalam Mengatasi Hambatan Tutor dalam Pembelajaran Program Paket B Setara SMP

Berdasarkan observasi dan wawancara yang dilakukan menyangkut hambatan-hambatan atau kesulitan yang dialami tutor dalam proses pembelajaran Kelompok Belajar Program Paket B Setara SMP di SKB Lubuk Begalung, upaya yang dilakukan SKB adalah sebagai berikut.

a. Upaya mengatasi hambatan dalam menyusun perencanaan pembelajaran. Hal ini dilakukan dengan cara sebagai berikut. (1) Pimpinan SKB menugaskan pengelola untuk membantu keperluan tutor menyangkut kurikulum dan materi ajar bagi warga belajar. (2) Pengelola dalam hal ini pamong belajar memberikan dan mencarikan petunjuk teknis Program Paket B untuk dapat dipedomani oleh tutor meskipun belum lengkap.

b. Upaya mengatasi hambatan dalam melaksanakan pembelajaran. Hal ini dilakukan dengan cara pengelola telah menunjuk piket untuk memantau dan membantu kebutuhan sarana dan prasarana serta bahan ajar, meskipun cenderung hanya mengusahakan agar proses belajar mengajar tidak terganggu seperti halnya menggantikan tutor yang tidak masuk.

c. Upaya mengatasi hambatan dalam menilai kemajuan belajar. Sejauh ini hal yang dilakukan hanya melakukan diskusi dan sedikit pengarahan kepada tutor, namun penilaian hasil belajar diserahkan kepada tutor masing-masing.

\section{Pembahasan}

Sebagai tenaga pendidik pada Program Paket B setara SLTP, tutor bertugas merencanakan dan melaksanakan proses pembelajaran, menilai hasil pembelajaran, serta melakukan pembimbingan dan pelatihan sehingga diharapkan lulusan Program Paket $B$ memenuhi standar kompetensi yang dipersyaratkan.

Berdasarkan temuan dalam penelitian ini, diperoleh bahwa terdapat beberapa hambatan yang dialami tutor dalam menjalankan tugas dan fungsinya tersebut yaitu sebagai berikut.

1. Kurangnya ketersediaan kurikulum.

2. Kurangnya petunjuk teknis pelaksanaan oleh pengelola program.

3. Kurangnya ketersediaan sarana dan prasarana pendukung proses belajar mengajar.

4. Kurangnya ketersediaan rujukan dan buku sumber bagi wajib belajar.

5. Kurangnya pengawasan dan pengendalian oleh pengelola program terhadap tutor (kurangnya komunikasi antara pengelola dan tutor).

6. Belum dilakukannya perencanaan pembelajaran dengan baik mengakibatkan kesulitan untuk melakukan evaluasi karena tidak ada patokan yang jelas baik proses maupun hasil belajar atau kompetensi yang seharusnya ditampilkan.

7. Kurangnya pengarahan dan pembinaan oleh pengelola program terhadap tutor, khususnya mengenai tolok ukur penilaian kemajuan belajar warga belajar.

Secara umum dapat dilihat bahwa hambatanhambatan tersebut di atas memperlihatkan kompetensi tutor yang belum memadai mengingat sebagian masalah tersebut sebenarnya dapat diatasi sendiri oleh tutor di samping kerjasama dan komunikasi dengan pengelola. Pengelola, yang dalam hal ini adalah tenaga pamong belajar SKB Lubuk Begalung dirasakan masih belum maksimal mengelola program ini, hal ini terlihat dari beberapa hambatan yang muncul tersebut menyangkut peran pengelola dalam melakukan pembinaan, pengarahan, dan pengendalian program.

Oleh karena itu, pada masa yang akan datang hambatan-hambatan yang dialami oleh tutor pada pelaksanaan Program Paket B setara SLTP di SKB Lubuk begalung perlu diatasi antara lain dengan cara sebagai berikut.

1. Peningkatan kompetensi tutor, dengan cara pembekalan baik dalam hal perencanaan, proses dan melakukan evaluasi pembelajaran.

2. Peningkatan kompetensi manajerial pamong belajar 
sebagai pengelola program, dengan cara pelatihan, studi banding atau magang pada institusi yang telah melaksanaan program sejenis secara lebih baik.

3. Perhatian dan dukungan yang lebih baik dari pimpinan SKB terutama dalam rangka pemenuhan kebutuhan pendukung baik sarana maupun prasarana serta penyediaan bahan rujukan untuk Program Paket B setara SLTP ini.
Perlu diingat bahwa ujung tombak proses pembelajaran Program Paket B adalah peran tutor sebagai agen pembelajaran (learning agent) meliputi kompetensi pedagogik, kompetensi kepribadian, kompetensi profesional, dan kompetensi sosial disamping harus memenuhi persyaratan kualifikasi pendidikan sebagaimana yang ditetapkan.

\section{KESIMPULAN}

\section{Kesimpulan}

Dari temuan umum yang diperoleh disimpulkan beberapa hal sebagai berikut.

1. Warga belajar Program Paket B setara SMP kelas 1, 2, dan 3 masih dalam usia sekolah (wajib belajar) dan berdasarkan jumlahnya cukup ideal untuk berlangsungnya proses pembelajaran yang efektif. Jumlah warga belajar pada suatu kelas tidak terlalu sedikit dan juga tidak terlalu banyak sehingga memungkinkan bagi tutor untuk melakukan pendekatan individual.

2. Tutor sebagian besar memenuhi standar kualifikasi akademik sebagai pendidik dan mata pelajaran yang diajarkan sesuai dengan latar belakang pendidikannya serta telah memiliki wawasan program kesetaraan.

3. Program pembelajaran telah disusun dalam bentuk jadwal dan mengikuti acuan kurikulum Program Paket B setara SMP, untuk semua mata pelajaran kecuali kerumahtanggaan, ekonomi lokal, keterampilan mata pencaharian/muatan lokal, teknologi informasi dan komunikasi, serta etika bekerja.

Dari berbagai temuan khusus yang diperoleh dalam penelitian ini, disimpulkan beberapa hal sebagai berikut.

1. Hambatan-hambatan yang dialami tutor dalam melaksanakan tugas pembelajaran pada kelompok belajar Program Paket B setara SMP baik pada kelas 1, 2, maupun 3 adalah: (1) kurangnya ketersediaan kurikulum, (2) kurangnya petunjuk teknis pelaksanaan oleh pengelola program, (3) kurangnya ketersediaan sarana dan prasarana pendukung proses belajar mengajar, (4) kurangnya ketersediaan rujukan dan buku sumber bagi wajib belajar, (5) kurangnya pengawasan dan pengendalian oleh pengelola program terhadap tutor (kurangnya komunikasi antara pengelola dan tutor), (6) belum dilakukannya perencanaan pembelajaran dengan baik mengakibatkan kesulitan untuk melakukan evaluasi karena tidak ada patokan yang jelas baik proses maupun hasil belajar atau kompetensi yang seharusnya ditampilkan, (7) kurangnya pengarahan dan pembinaan oleh pengelola program terhadap tutor, khususnya mengenai tolok ukur penilaian kemajuan belajar warga belajar.

2. Dari hambatan-hambatan tersebut di atas, hambatan yang paling dominan dialami tutor Program Paket B setara SMP dalam melaksanakan tugas pembelajaran di SKB Lubuk Begalung adalah pada aspek manajerial yaitu kurangnya pembinaan/ pengawasan/kendali oleh pengelola terhadap tutor dalam hal pengelola tidak menyiapkan kurikulum dan buku sumber sebagai pegangan yang mesti dilaksanakan oleh tutor sehingga tutor tidak dapat melakukan perencanaan pembelajaran dengan baik. Di samping itu, kurangnya pembinaan/kendali/ pengawasan oleh pengelola menyebabkan rendahnya motivasi berprestasi tutor. Pada sisi lain kompetensi tutor juga dapat menjadi hambatan yang berarti.

\section{Saran}

1. Pimpinan SKB perlu memperhatikan dan memberi dukungan terutama pemenuhan kebutuhan pendukung baik sarana maupun prasarana serta bahan rujukan untuk Program Paket B setara SLTP ini. Disamping itu perlu dilakukan pembekalan dan pelatihan baik terhadap tutor maupun pengelola program.

2. Pengelola Program Paket B setara SLTP hendaknya memberi perhatian lebih dalam melakukan pembinaan/pengawasan/kendali pelaksanaan tugas tutor termasuk dalam hal menyiapkan segala sesuatu yang mendukung terlaksananya proses pembelajaran dengan baik dan lancar.

3. Tutor sendiri hendaknya dapat lebih berinisiatif dalam mengatasi hambatan yang ditemuinya dalam pelaksanakan tugasnya sehingga tidak menjadikan alasan yang menyebabkan proses pembelajaran Program Paket B setara SLTP menjadi kurang mencapai sasaran yang diharapkan. 


\section{DAFTAR PUSTAKA}

Alwasilah, C.A. (2002). Pokoknya kualitatif: Dasardasar merancang dan melakukan penelitian kualitatif. Jakarta: PT. Dunia Pustaka Jaya.

Boqdan, R \& Biklen, S.K. (1982). Qualitative research for education: An introduction to theory and method. Boston: Allyn and Bacon.

Danim, S. (2002). Menjadi peneliti kualitatif. Bandung: CV. Pustaka Setia.

Depdiknas. (2004). Acuan kurikulum pendidikan kesetaraan program paket $A B C$. Jakarta: Ditjen PLSP.

Depdiknas. (2004). Acuan ketuntasan belajar pendidikan kesetaraan program paket $A B C$. Jakarta: Ditjen PLSP

Depdiknas. (2005). Penyelenggaraan pendidikan kesetaraan Program Paket B setara SMP. Jakarta: Ditjen PLSP.

Dharma, A. (1992). Manajemen perilaku organisasi: Pendayagunaan sumber daya manusia. Jakarta: Erlangga.

Fathurrohman, P. (2007). Strategi belajar mengajar melalui pemahaman konsep umum dan konsep islami. Bandung: Refika Aditama

Lunenburg, F.C. \& Alland. (2000). Educational administration: Concept and practices. Third
Edition. USA: Wardsworth Thomson Learning Stanford.

Moleong, L.J. (2004). Metodologi penelitian kualitatif. Bandung: Remaja Rosdakarya.

Rohidi, R.T. (1992). Analisis data kualitatif. Jakarta: Universitas Indonesia.

Sanafiah Faisal. (1990). Penelitian kualitatif: Dasardasar dan aplikasi. Malang: Yayasan Asih Asah Asuh.

Sanjaya, W. (2007). Strategi pembelajaran berorientasi standar proses pendidikan. Jakarta: Penerbit Kencana.

Spradley, S.P. (1980). Participant observation. New York: Halt Rinehart and Winston.

(2001). SK. Nomor: 54 Tahun 2001 Tentang Rincian Tugas Pokok Unit Pelaksana Teknis Dinas Sanggar Kegiatan Belajar. Padang: Pemerintah Kota Padang.

(2003). Undang-undang Republik Indonesia No. 20 Tahun 2003 tentang Sistem Pendidikan Nasional. Jakarta.

(2005). Pemerintah Republik Indonesia. Peraturan Pemerintah RI Nomor 19 Tahun 2005 tentang Standar Nasional Pendidikan. Jakarta: Penerbit Sinar Grafika. 